COSTING:Journal of Economic, Business and Accounting

Volume 2 Nomor 2, Juni 2019

e-ISSN : 2597-5234

https://doi.org/10.31539/costing.v2i2.562

\title{
ANALISIS FAKTOR-FAKTOR YANG MEMPENGARUHI MINAT PEMANFAATAN TEKNOLOGI INFORMASI BAGI AUDITOR
}

\section{ANALYZING OF FACTORS THAT AFFECT THE INTEREST IN USING INFORMATION TECHNOLOGY FOR AUDITORS}

\author{
Dian Puji Puspita Sari ${ }^{1}$, Arief Rahman ${ }^{2}$ \\ Universitas Muhammadiyah Riau ${ }^{1,2}$ \\ dianpuji@umri.ac.id ${ }^{1}$ \\ Submit,24-02-2019 Accepted,01-04-2019 Publish,03-04-2019
}

\begin{abstract}
The era of modernization nowadays, humans are very dependent on technology. This makes technology become a basic need for everyone. This study aims to analyze the factors that influence the interest in using information technology for auditors in Yogyakarta. Independent variables used include performance expectations, business expectations, social factors, conditions that facilitate and suitability of tasks. Respondents in this study were auditors who used IT in their work. The number of respondents was 106 respondents. The data analysis method used is structural Equation Model (SEM) using Partial Least Square (PLS) software. The results of this study state that performance expectations, business expectations, social factors, facilitating conditions and suitability of tasks have a positive effect on the interest in using information technology for auditors in Yogyakarta.
\end{abstract}

Keywords: Interest, Information Technology, Auditor

\begin{abstract}
ABSTRAK
Era modernisasi seperti sekarang, manusia sangat bergantung pada teknologi. Hal ini membuat teknologi menjadi kebutuhan dasar setiap orang. Penelitian ini bertujuan untuk menganalisis faktor-faktor yang berpengaruh terhadap minat pemanfaatan teknologi informasi bagi auditor di Yogyakarta. Variabel independen yang digunakan antara lain ekspektasi kinerja, ekspektasi usaha, faktor sosial, kondisi yang memfasilitasi dan kesesuaian tugas. Responden dalam penelitian ini adalah para auditor yang menggunakan TI dalam melakukan perkerjaanya.Jumlah responden sebanyak 106 responden. Metode analisis data yang digunakan adalah structural Equation Model (SEM) dengan menggunakan software Partial Least Square (PLS). Hasil penelitian ini menyatakan bahwa ekspektasi kinerja, ekspektasi usaha, faktor sosial, kondisi yang memfasilitasi dan kesesuaian tugas berpengaruh positif terhadap minat pemanfaatan teknologi informasi bagi auditor di Yogyakarta.
\end{abstract}

Kata Kunci: Minat, Teknologi Informasi, Auditor 


\section{PENDAHULUAN}

Teknologi di masa globalisasi atau modernisasi seperti saat ini sudah berkembang pesat. Hal ini dapat dibuktikan dengan banyaknya inovasiinovasi yang telah dibuat di dunia ini. Modernisasi sendiri dalam ilmu sosial merujuk pada bentuk transformasi dari keadaan yang kurang maju atau kurang berkembang ke arah yang lebih baik dengan harapan kehidupan masyarakat akan menjadi lebih baik. Modernisasi mencakup banyak bidang, contohnya dalam bidang ilmu pengetahuan dan teknologi. Di zaman modernisasi seperti sekarang, manusia sangat bergantung pada teknologi. Hal ini membuat teknologi menjadi kebutuhan dasar setiap orang. Dari orang tua hingga anak muda, para ahli hingga orang awam pun menggunakan teknologi dalam berbagai aspek kehidupannya. Perkembangan teknologi saat ini merupakan dasar untuk mengembangkan kehidupan berbangsa dan bernegara. Kemajuan suatu negara didasarkan atas seberapa jauh ilmu pengetahuan dan teknologi yang dikuasai oleh negara tersebut. Hal ini sangat beralasan dikarenakan ilmu pengetahuan dan teknologi merupakan dasar dari setiap aspek kehidupan.

Peningkatan penggunaan teknologi komputer sebagai salah satu bentuk pengembangan teknologi informasi telah banyak mengubah pemrosesan data akuntasi secara manual menjadi otomatis. Teknologi informasi dalam suatu perusahaan akan membantu penyediaan informasi dengan cepat sesuai dengan kebutuhan manajer dalam pengambilan keputusan, selain itu teknologi informasi tidak hanya digunakan dalam pengolah data, namun juga dapat digunakan untuk mengetahui lebih cepat jika timbul permasalahan dalam organisasi. Teknologi informasi digunakan untuk meningkatkan kinerja para individu sebagai anggota organisasi bisnis yang secara agregat diharapkan dapat meningkatkan kinerja organisasi. Oleh karena itu hal penting yang harus diperhatikan oleh pelaku bisnis dalam menerapkan teknologi informasi adalah sejauh mana keberhasilan sistem tersebut membawa dampak positif dalam peningkatan kinerja baik individu maupun organisasi secara keseluruhan.

Dampak dari peningkatan penggunaan teknologi informasi mempengaruhi perkembangan proses audit bagi para auditor. Dimana para auditor diharuskan menggunakan software audit yang memfasilitasi pendekatan audit berbasis computer sehingga akan memudahkan auditor dalam melakukan proses pekerjaanya. Hal tersebut dikarenakan teknologi informasi mampu memproses informasi secara konsisten. Sistem TI dapat mengurangi salah saji dengan mengganti prosedur manual dengan pengendalian terprogram yang menerapkan pengecekan dan penyeimbangan setiap transaksi yang diproses. Ini mengurangi kesalahan manusia yang sering terjadi dalam pemrosesan transaksi secara manual.

Pengendalian keamanan secara online atas aplikasi, database, dan sistem operasi serta dapat memperbaiki pemisahan tugas, yang mengurangi kesempatan untuk melakukan kecurangan. Berdasarkan manfaat yang didapat dari penggunaan system informasi dalam proses audit dapat meningkatkan minatpemanfaatan system informasi bagi auditor karena dapat membuat proses audit jadi lebih efisien dan efektif serta menghindarkan dari human error.

Hal tersebut diatas didukung oleh Jatmiko (2012) yang menyatakan bahwa penggunaan teknologi informasi telah mengalami peningkatan yang 
pesat bahkan pengembangannya telah banyak mengubah pemrosesan data akuntansi secara otomatis. Perubahan tersebut sangat mempengaruhi dunia audit karena laporan keuangan yang nantinya dihasilkan dari proses akuntansi merupakan objek dari bidang praktik audit. Perkembangan tersebut akan memudahkan perusahaan dalam proses akuntansi dimana data lebih banyak tersimpan dalam media elektronik. Peran dari komputer pun telah banyak mengubah proses audit baik dari input sampai output sudah terkomputerisasi dengan baik. Keberhasilan penerapan suatu teknologi informasi bergantung pada kemudahan dan pemanfaatan sistem tersebut oleh pemakai sistem karena teknologi sistem informasi diselenggarakan dalam suatu perusahaan untuk membantu individu dalam menyelesaikan tugasnya (Goodhue dan Thompson, 1995).

Oleh sebab itu, penerapan teknologi dalam sistem informasi perusahaan atau organisasi hendaknya mempertimbangkan pemakai sistem sehingga teknologi yang diterapkan sesuai dengan tugas dan kemampuan pemakai. Tidak jarang teknologi yang diterapkan dalam sistem informasi kurang memberikan manfaat dalam meningkatkan kinerja individu karena tidak sesuai dengan kebutuhan pengguna (Jumaili, 2005). Manfaat penggunaan teknologi informasi dapat diukur melalui suatu evaluasi yang dapat memberikan gambaran keberhasilan sistem itu sendiri. Model evaluasi pemanfaatan dan penggunaan teknologi informasi telah banyak dikembangkan oleh para peneliti.

Penerapan suatu sistem informasi bergantung pada kemudahan dan pemanfaatan sistem tersebut oleh pemakai sistem karena teknologi sistem informasi diselenggarakan dalam suatu perusahaan untuk membantu individu dalam menyelesaikan tugasnya (Goodhue dan Thompson, 1995). Oleh sebab itu, penerapan teknologi dalam sistem informasi perusahaan atau organisasi hendaknya mempertimbangkan pemakai sistem sehingga teknologi yang diterapkan sesuai dengan tugas dan kemampuan pemakai. Tidak jarang teknologi yang diterapkan dalam sistem informasi kurang memberikan manfaat dalam meningkatkan kinerja individu karena tidak sesuai dengan kebutuhan pengguna (Jumaili, 2005).

Manfaat penggunaan teknologi informasi dapat diukur melalui suatu evaluasi yang dapat memberikan gambaran keberhasilan sistem itu sendiri . Model evaluasi pemanfaatan dan penggunaan teknologi informasi telah banyak dikembangkan oleh para peneliti. Venkatesh et al (2003) melakukan penelitian mengenai Unified Theory of Acceptance and Use of Technology (UTAUT). Penelitian dilakukan untuk mereview dan menggabungkan beberapa model penerimaan teknologi informasi dan menghipotesiskan ekspektasi kinerja misalnya ekspektasi kinerja dari system yang digunakan, persepsi pengguna mengenai usaha yang dibutuhkan untuk menggunakan system baru misalnya ekspektasi usaha, persepsi pengguna apakah pengaruh lingkungan yang dapat mendorong penggunaan sistem misalnya pengaruh sosial dan ekspektasi pengguna mengenai keberadaan infrastruktur organisasi dan teknis untuk mendukung penggunaan sistem misalnya kondisi yang memfasilitasi.

Ekspektasi kinerja didefinisikan sebagai tingkat dimana seorang individu menyakini bahwa dengan menggunakan sistem akan membantu dalam meningkatkan kinerjanya (Hamzah, 2010). Handayani (2007) menyatakan 
bahwa konstruk ekspektasi kinerja merupakan prediktor yang kuat dari minat pemanfaatan SI dalam setting sukarela maupun wajib. Penelitian Hamzah (2009) menunjukkan ekspektasi kinerja berpengaruh signifikan terhadap pemanfaatan sistem informasi. Handayani (2007) menunjukkan ekspektasi kinerja mempunyai pengaruh positif signifikan terhadap minat pemanfaatan SI artinya responden yakin bahwa dengan menggunakan sistem akan membantu dalam meningkatkan kinerjanya. Dengan demikian dapat dikembangkan hipotesis sebagai berikut:

$H 1$ : Ekspetasi kinerja berpengaruh positif terhadap minat pemanfaatan teknologi informasi.

Ekspektasi usaha merupakan tingkat kemudahan penggunaan sistem yang akan dapat mengurangi upaya (tenaga dan waktu) individu dalam melakukan pekerjaan (Venkatesh, et al., 2003). Kemudahan penggunaan SI akan menimbulkan perasaan dalam diri seseorang bahwa sistem itu mempunyai kegunaan dan karenanya menimbulkan rasa yang nyaman bila bekerja dengan menggunakannya (Venkatesh et al., 2000). (Venkatesh, et al., 2003) menyatakan bahwa terdapat adanya hubungan langsung dan signifikan antara minat pemanfaatan SI terhadap penggunaan SI. Hasil penelitian dari Hamzah (2010) menunjukkan bahwa ekspektasi usaha berpengaruh signifikan terhadap pemanfaatan sistem informasi. Dengan demikian dapat dikembangkan hipotesis sebagai berikut: $\mathrm{H2}$ : Ekspektasi usaha berpengaruh positif terhadap minat pemanfaatan teknologi informasi.

Faktor sosial diartikan sebagai tingkat dimana seorang individu menganggap bahwa orang lain meyakinkan dirinya bahwa dia harus menggunakan teknologi informasi.
Besarnya keyakinan dari oranglain seperti dukungan dari rekan kerja, atasan maupun organisasi akan memberikan pengaruh yang positif bagi faktor sosial dalam mempengaruhi seorang individu untuk memanfaatkan teknologi informasi (Wulandari dan Sudarno, 2012). Hasil penelitian Darmini, dalam Wulandari dan Sudarno (2012) mengindikasikan pemanfaatan teknologi informasi dan kepercayaan terhadap teknologi secara parsial berpengaruh positif dann signifikan terhadap kinerja individual. Selain itu, Rahmawati (2008) menemukan bahwa faktor sosial memiliki pengaruh yang signifikan terhadap pemanfaatan teknologi informasi. Dengan demikian dapat dikembangkan hipotesis sebagai berikut: $H 3$ : Faktor sosial berpengaruh positif terhadap minat pemanfaatan teknologi informasi.

Dalam konteks pemanfaatan teknologi informasi, kondisi yang memfasilitasi dapat dimasukkan sebagai faktor yang mempengaruhi pemanfaatan teknologi informasi. Hal tersebut dapat berupa tersedianya pedoman yang cukup lengkap dalam menjalankan program teknologi informasi serta tersedianya pelatihan yang dapat membantu individu bila mengalami kesulitan dalam penggunaan teknologi informasi yang akan mendorong individu untuk memanfaatkan teknologi informasi secara maksimal (Wulandari dan Sudarno, 2012). Berdasarkan pengujian tersebut pengaruh variabel kondisi yang memfasilitasi terhadap pemanfaatan teknologi informasi menunjukkan bahwa kondisi yang memfasilitasi berpengaruh positif terhadap pemanfaatan teknologi informasi. Dengan demikian dapat dikembangkan hipotesis sebagai berikut: $H 4$ : Kondisi yang memfasilitasi pemakai berpengaruh 
positif terhadap minat pemanfaatan teknlogi informasi.

Kesesuaian tugas diukur dengan mengetahui apakah individu yakin bahwa dengan pemanfaatan teknologi informasi dapat meningkatkan kinerja individual tersebut. Amalia (2010) melakukan pengujian faktor kesesuaian tugas pada KPP Pratama Tegal. Hasil Penelitian menunjukkan hubungan yang positif dan signifikan antara kesesuaian tugas dengan pemanfaatan teknologi informasi. Hal yang sama juga ditunjukkan dalam penelitian Siregar et al. (2008) yang melakukan pengujian pada KPP Pratama Denpasar Barat serta Sigalotang (2006) melakukan pengujian pada karyawan bank di Makassar. Berdasarkan penelitian tersebut, peneliti mengajukan hipotesis sebagai berikut :

H5 : kesesuaian tugas berpengaruh positif terhadap minat pemanfaatan teknologi informasi.

\section{KERANGKA PEMIKIRAN}

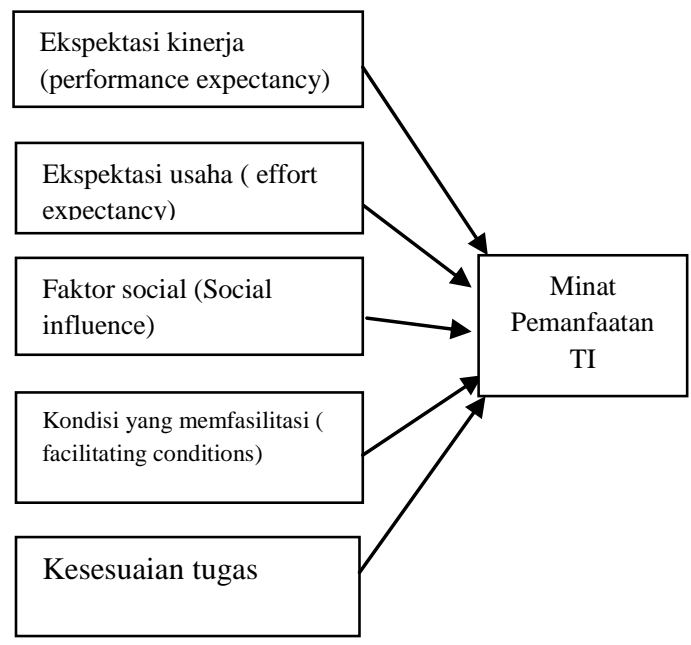

\section{Gambar 1 Kerangka Pemikiran}

\section{METODE PENELITIAN}

Populasi yang digunakan dalam penelitian ini adalah auditor yang bekerja pada Kantor Akuntan Publik (KAP) di Yogyakarta sebagai responden untuk mengetahui faktor-faktor yang mempengaruhi minat pemanfaatan teknologi informasi auditor . Terdapat 13 KAP di Yogyakarta tetapi pada penelitian ini kuisioner yang disebar hanya 10 KAP dikarenakan 3 KAP menolak. Penelitian ini dilakukan di Yogyakarta karna menurut penulis auditor di Yogyakarta sudah mempunyai SDM yang cukup bagus sehingga penguasaan pada TI cukup baik dan mengakibatkan kualitas yang tinggi dan pemanfaatan terhadap TI yang tinggi maka dari itu mendorong penulis untuk melakukan penelitian di Yogyakarta.

Sumber data dalam penelitian ini meliputi data primer yang berasal dari sumber data yang dikumpulkan secara khusus dan berhubungan langsung dengan permasalahan yang diteliti. Dalam hal ini, data primer yang digunakan adalah hasil jawaban responden atas kuesioner yang dibagikan. Metode pengumpulan data melalui kuesioner yang dibagikan kepada responden yaitu auditor yang bekerja pada KAP di DIY yang terdiri dari dua bagian: 1) bagian pertama terdiri dari pertanyaan yang berkaitan dengan data pribadi responden, 2) bagian kedua digunakan untuk memperoleh data mengenai dimensi pertanyaan dengan menggunakan skala Likert.

Tujuan pengujian validitas adalah untuk mengetahui sejauh mana ketepatan dan kecermatan suatu alat ukur dalam melakukan fungsi ukurnya. Suatu instrumen pengukuran dikatakan mempunyai validitas yang tinggi bila alat ukur tersebut memberikan hasil ukur yang sesuai dengan maksud dilakukannya pengukuran tersebut. Uji validitas dilakukan untuk menilai seberapa baik suatu instrument atau pun proses pengukuran terhadap konsep yang diharapkan untuk mengetahui apakah yang kita tanyakan dalam kuesioner sudah sesuai dengan 
konsepnya. Data dikatakan valid apabila skor indikator masing-masing pertanyaan berkorelasi secara signifikan terhadap skor total konstruk. Hasil uji validitas dilakukan untuk masingmasing indikator. Ketentuan validitas intrumen apabila $r$ hitung lebih besar dengan $r$ tabel. Dasar pengambilan keputusan, $\mathrm{r}$ hitung $>\mathrm{r}$ table maka variabel valid. $\mathrm{r}$ hitung $<\mathrm{r}$ table maka variabel tidak valid (Ghozali 2008).

Setelah pengujian validitas, maka tahap selanjutnya adalah pengujian reliabilitas. Uji reliabilitas adalah proses pengukuran terhadap ketepatan (konsisten) dari suatu instrumen. Pengujian ini dimaksudkan untuk menjamin instrumen yang digunakan merupakan sebuah instrumen yang handal, konsistensi, stabil dan dependibalitas, sehingga bila digunakan berkali-kali dapat menghasilkan data yang sama. Uji reliabilitas mengindikasikan bahwa suatu indikator tidak bias dan sejauh mana suatu indikator handal pada waktu, tempat dan orang yang berbeda-beda. Untuk mengukur reliabilitas dari indikator penelitian ini dilakukan dengan menggunakan koefisien Cronbach's Alpha. Koefisien Cronbach's Alpha yang mendekati satu menandakan reliabilitas konsistensi yang tinggi. Cronbach's alpha digunakan untuk mengukur keandalan indikator-indikator yang digunakan dalam kuesioner penelitian. Uji reliabilitas merupakan uji yang dilakukan untuk mengukur apakah kuesioner benar-benar merupakan indikator yang mengukur suatu variabel. Suatu kuesioner dikatakan reliabel apabila jawaban seseorang konsisten dari waktu ke waktu.

Pengujian hipotesis penelitian dilakukan dengan pendekatan structural Equation Model (SEM) dengan menggunakan software Partial Least Square (PLS). PLS adalah model persamaan struktural (SEM) yang berbasis komponen atau varian (variance). SEM adalah sebuah model statistik yang memberikan perkiraan perhitungan dari hubungan hipotesis di antara variabel dalam sebuah model teoritis baik secara langsung maupun tak langsung. Seringkali SEM juga disebut sebagai kombinasi antara analisis faktor dan analisis jalur. SEM mengacu kepada hubungan antara variabel endogen (endogenous variables) dan variabel eksogen (exogenous variables), yang merupakan variabel tidak dapat diamati atau dihitung (unobserved variables). SEM merupakan tekhnik analisis statistik multivariant yang merupakan kombinasi dari tekhnik analisis faktor dan analisis regresi. SEM bertujuan untuk menguji hubungan-hubungan antar variable yang ada pada suatu model. Sebelum dikembangkan program aplikasi computer sebagai alat analisis SEM, penggunaan SEM masih terbatas karena kompleksitas penghitungan matematis yang dimilikinya.

Menurut Ghozali (2008) PLS merupakan pendekatan alternatif yang bergeser dari pendekatan SEM berbasis covariance menjadi berbasis varian. SEM yang berbasis kovarian umumnya menguji kausalitas/teori, sedangkan PLS lebih bersifat predictive model. PLS merupakan metode analisis yang powerfull Ghozali (2008) karena tidak didasarkan pada banyak asumsi, misalnya data harus terdistribusi normal dan sampel tidak harus besar. Selain dapat digunakan untuk mengkonfirmasi teori, PLS juga dapat digunakan untuk menjelaskan ada tidaknya hubungan antar variabel laten. PLS dapat sekaligus menganalisis konstruk yang dibentuk dengan indikator refleksif dan formatif. Hal ini tidak dapat dilakukan oleh SEM yang berbasis kovarian karena akan menjadi 
unidentified model. Ghozali (2008) tujuan PLS adalah membantu peneliti untuk tujuan prediksi. Model formalnya mendefinisikan variabel laten adalah linear agregat dari indikator-indikatornya. Weight estimate untuk menciptakan komponen skor variabel laten didapat berdasarkan bagaimana inner model (model struktural yang menghubungkan antar variabel laten) dan outer model (model pengukuran yaitu hubungan antar indikator dengan konstruknya) dispesifikasi. Hasilnya adalah residual variance dari variabel dependen (keduanya variabel laten dan indikator) diminumkan.Estimasi parameter yang didapat dengan PLS dapat dikategorikan menjadi tiga. Pertama, adalah weight estimate yang digunakan untuk menciptakan skor variabel laten. Kedua, mencerminkan estimasi jalur (path estimate) yang menghubungakan variabel laten dan antar variabel laten dan blok indikatornya (loading). Ketiga adalah berkaitan dengan mean dan lokasi parameter (nilai konstan regresi) untuk indikator dan variabel laten. Untuk memperoleh ketiga estimasi ini, PLS menggunakan proses iterasi tiga tahap dan setiap tahap iterasi menghasilkan estimasi. Tahap pertama, menghasilkan weight estimate, tahap kedua mengahsilkan estimasi untuk inner model dan outer model, dan tahap ketiga menghasilkan estimasi means dan lokasi (konstanta). Dalam analisis dengan menggunakan PLS ada 2 hal yang dilakukan yaitu:

\section{Menilai outer model atau measurement model.}

Ada tiga kriteria untuk menilai outer model yaitu Convergent Validity, Discriminant Validity dan Composite Reliability. Convergent validity dari model pengukuran dengan refleksif indikator dinilai berdasarkan korelasi antara item score/componen score yang dihitung dengan PLS. Ukuran refleksif individual dikatakan tinggi jika berkorelasi lebih dari 0,70 dengan konstruk yang diukur. Namun menurut Chin (1998) dalam Ghozali (2008) untuk penelitian tahap awal dari pengembangan skala pengukuran nilai loading 0,5 sampai 0,6 dianggap cukup memadai. Discriminant Validity dari model pengukuran dengan refleksif indikator dinilai berdasarkan Cross Loading pengukuran dengan konstruk. Jika korelasi konstruk dengan item pengukuran lebih besar daripada ukuran konstruk lainnya, maka hal tersebut menunjukkan konstruk laten memprediksi ukuran pada blok mereka lebih baik daripada ukuran pada blok lainnya.

Metode lain untuk menilai Discriminant Validity adalah membandingkan nilai square root of average variance extracted (AVE) setiap konstruk dengan korelasi antara konstruk dengan konstruk lainnya dalam model Ghozali (2008) . Jika nilai akar kuadrat AVE setiap konstruk lebih besar daripada nilai korelasi antar konstruk dengan konstruk lainnya dalam model, maka dikatakan memiliki nilai discriminant validity yang baik. Pengukuran ini dapat digunakan untuk mengukur reliabilitas component score variabel laten dan hasilnya lebih konservatif dibandingkan dengan composite reliability. Direkomendasikan nilan AVE harus lebih besar 0,50 (Fornell dan Larcker, 1981 dalam Imam Ghozali, 2008). Composite reability yang mengukur suatu konstruk dapat dievaluasi dengan dua macam ukuran yaitu internal consistency dan Cronbach's Alpha (Ghozali, 2008). 


\section{Menilai Inner Model atau Structural Model}

Pengujian inner model atau model struktural dilakukan untuk melihat hubungan antara konstruk, nilai signifikansi dan R-square dari model penelitian. Model struktural dievaluasi dengan menggunakan $\mathrm{R}$ square untuk konstruk dependen, Stone-Geisser Q-square test untuk predictive relevance dan uji serta signifikansi dari koefisien parameter jalur struktural. Dalam menilai model dengan PLS dimulai dengan melihat Rsquare untuk setiap variabel laten dependen. Interpretasinya sama dengan interpretasi pada regresi.

Perubahan nilai R-square dapat digunakan untuk menilai pengaruh variabel laten indepanden tertentu terhadap variabel laten dependen apakah mempunyai pengaruh yang substantif (Ghozali, 2008). Disamping melihat model R-square, model PLS juga dievaluasi dengan melihat Qsquare predictive relevance untuk model konstruk. Q-square mengukur seberapa baik nilai observasi dihasilkan oleh model dan juga estimasi parameternya.

\section{HASIL DAN PEMBAHASAN Pengujian Hipotesis Pertama (H1)}

Hipotesis pertama

menyatakan bahwa ekspektasi kinerja berpengaruh positif dengan minat pemanfaatan teknologi informasi. Hasil pengujian menggunakan partial least square (PLS) menunjukkan bahwa koefisien path pada variabel ekspektasi kinerja 0,319 dan nilai $\mathrm{T}$ Statistik sebesar 4,281 (lebih besar dari t tabel yaitu sebesar 1,96) dan p-value sebesar $0,000<0,05$. Sehingga dapat diartikan bahwa ekspektasi kinerja berpengaruh positif terhadap minat pemanfaatan teknologi informasi, dengan demikian Ha1 didukung. Hasil penelitian ini sejalan dengan penelitian Hamzah (2009) menunjukkan ekspektasi kinerja berpengaruh signifikan terhadap pemanfaatan sistem informasi.

\section{Pengujian Hipotesis Kedua (H2)}

Hipotesis kedua menyatakan bahwa Ekspektasi usaha berpengaruh positif terhadap minat pemanfaatan sistem informasi. Hasil pengujian menggunakan partial least square (PLS) menunjukkan bahwa koefisien path pada variabel ekspektasi usaha sebesar 0,145 dan nilai $\mathrm{T}$ Statistik sebesar 2,426 (lebih besar dari t tabel yaitu sebesar 1,96) dan p-value sebesar $0,016<0,05$. Sehingga dapat diartikan bahwa ekspektasi usaha berpengaruh positif dan signifikan terhadap minat pemanfaatan teknologi informasi, dengan demikian $\mathbf{H 2}$ didukung. Hasil ini mendukung penelitian dari Hamzah (2010) menunjukkan bahwa ekspektasi usaha berpengaruh signifikan terhadap pemanfaatan sistem informasi.

\section{Pengujian Hipotesis Ketiga (H3)}

Hipotesis ketiga (H3) menyatakan bahwa Faktor sosial berpengaruh positif terhadap minat pemanfaatan sistem informasi. Hasil pengujian menggunakan partial least square (PLS) menunjukkan bahwa koefisien path pada variabel faktor sosial terhadap minat pemanfaatan teknologi informasi sebesar 0,181 dan nilai $\mathrm{T}$ Statistik sebesar 2,126 (lebih besar dari t tabel yaitu sebesar 1,96) dan p-value sebesar $0,034<0,05$. Hal ini berarti faktor sosial berpengaruh signifikan terhadap minat pemanfaatan teknologi informasi, sehingga $\mathbf{H 3}$ didukung. Hasil penelitian ini mendukung penelitian sebelumnya oleh Rahmawati (2008) yang menemukan bahwa faktor sosial memiliki pengaruh yang signifikan terhadap pemanfaatan teknologi informasi. 
Pengujian Hipotesis Keempat (H4)

Hipotesis keempat (H4) menyatakan bahwa Kondisi yang memfasilitasi pemakai berpengaruh positif terhadap minat pemanfaatan sistem informasi. Hasil pengujian menggunakan partial least square (PLS) menunjukkan bahwa koefisien path pada variabel kondisi yang memfasilitasi terhadap minat pemanfaatan teknologi informasi sebesar 0,276 dan nilai $\mathrm{T}$ Statistik sebesar 4,312 (lebih besar dari t tabel yaitu sebesar 1,96) dan p-value sebesar $0,000<0,05$. Hal ini berarti kondisi yang memfasilitasi berpengaruh signifikan terhadap minat pemanfaatan teknologi informasi sehingga $\mathbf{H 4}$ didukung. Hasil penelitian sejalan dengan penelitian Wulandari dan Sudarno (2012) dimana variabel kondisi yang memfasilitasi memiliki pengaruh signidikan terhadap pemanfaatan teknologi informasi.

\section{Pengujian Hipotesis Kelima (H5)}

Hipotesis ketiga (H5) menyatakan bahwa Terdapat pengaruh yang positif antara kesesuaian tugas dengan pemanfaatan teknologi informasi. Hasil pengujian menggunakan partial least square (PLS) menunjukkan bahwa koefisien path pada variabel kesesuaian tugas terhadap minat pemanfaatan teknologi informasi sebesar 0,329 dan nilai $\mathrm{T}$ Statistik sebesar 3,632 (lebih besar dari t tabel yaitu sebesar 1,96) pada alpha sebesar 5\%, dan pengaruh kesesuaian tugas terhadap minat pemanfaatan teknologi informasi diperoleh koefisien path sebesar 0,329 dan $\mathrm{t}$ statistik sebesar 3,632>1,96 dan p-value sebesar $0,000<0,05$. Hal ini berarti kesesuaian tugas berpengaruh secara signifikan terhadap minat pemanfaatan teknologi informasi, sehingga $\mathbf{H 5}$ didukung.
Hasil penelitian sejalan dengan penelitian sebelumnya oleh Amalia (2010) yang menemukan bahwa faktor kesesuaian tugas menunjukkan hubungan yang positif dan signifikan terhadap pemanfaatan teknologi informasi.

\section{PENUTUP \\ Kesimpulan}

Berdasarkan hasil penelitian seperti yang telah diuraikan sebelumnya dapat ditarik beberapa kesimpulan bahwa Ekspektasi kinerja berpengaruh positif dan signifikan terhadap minat pemanfaatan teknologi informasi. Hal ini berarti semakin tinggi ekspektasi kinerja yang dimiliki auditor maka semakin besar minat pemanfaatan teknologi informasi. Hasil yang lain menemukan bahwa Ekspektasi usaha berpengaruh positif dan signifikan terhadap minat pemanfaatan teknologi informasi. Hal ini berarti semakin tinggi ekspektasi usaha yang dimiliki auditor maka semakin besar minat pemanfaatan teknologi informasi.

Begitu juga dengan Faktor sosial berpengaruh positif dan signifikan terhadap minat pemanfaatan teknologi informasi. Hal ini berarti semakin tinggi faktor sosial yang dirasakan auditor maka semakin besar minat pemanfaatan teknologi informasi dan kondisi yang memfasilitasi juga berpengaruh positif dan signifikan terhadap minat pemanfaatan teknologi informasi. Hal ini berarti semakin tinggi kondisi yang memfasilitasi yang dirasakan auditor maka semakin besar minat pemanfaatan teknologi informasi.

Sementara untuk variabel kesesuaian tugas selain berpengaruh positif dan signifikan terhadap minat pemanfaatan teknologi informasi, variabel ini juga terukti sebagai variabel yang paling berpengaruh atau dominan terhadap minat pemanfaatan teknologi 
informasi. Hal ini berarti semakin tinggi kesesuaian tugas yang dimiliki auditor maka semakin besar minat pemanfaatan teknologi informasi.

\section{Saran}

1. Bagi peneliti selanjutnya hendaknya melakukan penelitian yang sama yang didukung dengan melakukan oberservasi yang lebih banyak misalnya pada praktisi di lingkungan Industri.

2. Bagi pengelola sistem informasi khususnya di Kantor Akuntan Publik hendaknya mengedepankan pada faktor ekspektasi kinerja, ekspektasi usaha, faktor sosial, kondisi yang memfasilitasi dan kesesuaian tugas, karena kelima variabel tersebut mampu meningkatkan minat dalam menggunakan teknologi informasi. Sistem informasi dirancang agar mudah diakses, memberikan manfaat yang nyata bagi pegawai sehingga kinerjanya lebih efisien dan efektif serta panduan yang jelas. Selain itu pihak KAP harus memberikan dukungan yang besar dalam pengunaan sistem informasi, dengan memberikan tenaga-tenaga ahli serta sistem yang dibangun sesuai dengan tugas-tugas yang dapat mempercepat hasil kerja.

3. Bagi peneliti selanjutnya sebaiknya mengembangkan penelitian dengan melakukan wawancara tentang kendala-kendala apa saja yang menyebabkan dalam implementasi teknologi informasi tersebut.

\section{DAFTAR PUSTAKA}

Amalia, Soraya. (2010). Persepsi Pegawai Pajak terhadap Pemanfaatan Teknologi Informasi pada Kinerja Individual.Semarang. Skripsi Universitas Diponegoro.

Ghozali, Imam. (2008). Aplikasi Analisis Multivariate dengan Program SPSS. Semarang: Badan Penerbit Universitas Diponegoro.

Jatmiko, Nugroho. (2012). Analisis faktor-faktor yang mempengaruhi minat pemanfaatan dan penggunaan system E-ticket (Studi Empiris pada Biro Perjalanan di Kota Semarang). Universitas Dipenogoro.

Jumaili, Salman. (2005). “Kepercayaan Terhadap Teknologi Sistem Informasi Baru dalam Evaluasi Kinerja Individual". Simposium Nasional Akuntansi VIII. Solo, 15-16 September 2005.

Rahmawati, Diana. (2008). Analisis Faktor-Faktor yang Berpengaruh Terhadap Pemanfaatan Teknologi Informasi Jurnal Ekonomi dan Pendidikan. 5(1): 107-118.

Siregar, Astuti Handaryani \& I Ketut Suryanawa. (2009). Pemanfaatan Teknologi Informasi dan Pengaruhnya terhadap Kinerja Individual pada Kantor Pelayanan Pajak Pratama Denpasar Barat. Jurnal Akuntansi dan Bisnis. 4(2): 139-151.

Venkatesh, Davis, Morris. (2003). User Acceptance of Information Technology: Toward a Unified View," MIS Quarterl 
